\title{
Duró Edit \\ fogalmazó \\ Debreceni Törvényszék \\ A munkajog területén megvalósuló egyenlő bánásmód követelménye, valamint megsértésének módjai az Európai Bíróság és a magyar bírói gyakorlat tükrében
}

Debreceni Jogi Mühely, 2014. évi (XI. évfolyam) 3-4. szám (2014. december 30.)

\section{Bevezetés}

A diszkrimináció és az esélyegyenlőség nagy tömegeket érintő társadalmi és gazdasági probléma. Vannak olyan társadalmi csoportok, mint például a romák, a fogyatékkal élők, a nők, a fiatal és az idős munkavállalók, amelyek az átlagnál nagyobb valószínüséggel szembesülnek diszkriminációval. Más Európai Uniós országokhoz hasonlóan Magyarországon is a diszkrimináció az élet majd minden területét áthatja, és különösen tetten érhető a munkaerőpiacon, az oktatásban, az egészségügyi ellátásban, valamint a szolgáltatásokhoz való hozzáférésben.

A társadalomban megjelenő diszkrimináció közül a foglalkoztatási diszkrimináció okozza talán a legnagyobb problémát, mivel alapjaiban korlátozza valamennyi hátrányos helyzetü csoport társadalmi és gazdasági lehetőségeit. A foglalkoztatás terén megnyilvánuló diszkrimináció tehető nagyrészt felelőssé a romák, fogyatékossággal élők, nők, valamint fiatal és idősebb munkavállalók riasztóan alacsony foglalkoztatottságáért. Továbbá, ha van is hol dolgozniuk a fent említett csoportoknak, az általuk elérhető munka-jövedelmek, munkakörülmények és jogi biztonság lényegesen rosszabb az átlagnál. Kiszolgáltatottságuk miatt nagy a valószínűsége annak, hogy a hátrányos csoporthoz tartozó munkavállaló rosszul fizetett munkát végez bejelentés nélkül „feketén”, színlelt szerződéssel, kölcsönzött munkavállalóként, de a legjobb esetben is csak határozott idejü munkaszerződéssel.[1]

Mindezek mellett cikkem témájának választása azért is esett az egyenlő bánásmód követelményének megsértésre, mert munkám során azt tapasztaltam, hogy a munkavállalók egyre gyakrabban hivatkoznak ezen követelmény megsértésére.

Maga az új Mt. is deklarálja, hogy a munkaviszonnyal kapcsolatban az egyenlő bánásmód követelményét meg kell tartani. Ezen belül külön kiemeli, hogy különösen a munka díjazásával összefüggésben kell erre törekedni.

A felperesi pozícióban lévő munkavállalóknak azonban kisebb száma az, aki az egyenlő munkáért egyenlő bér elvének megsértésére alapítva indít keresetet a munkaügyi bíróságon. $\mathrm{Az}$ esetek többségében a munkaviszony megszüntetésekor kerül előtérbe az egyenlö bánásmód megsértése, és kerül bele a keresetlevelekbe az a hivatkozás, hogy az érintett személy jogviszonyának megszüntetésekor megsértették az egyenlő bánásmód követelményét. Megemlítendő még, hogy az esetek kisebb részben elöfordulhat a sikertelen munkahelyi felvételkor is a hátrányos megkülönböztetésre (mint az egyenlö bánásmód megsértésének egy formájára) történő hivatkozás.

Fentiek vezettek arra, hogy pontosabban és körültekintően vizsgáljam meg az egyenlő bánásmód követelményének mibenlétét, a követelmény megsértésének megnyilvánulásait, a követelmény megsértésének indokoltságát, valamint a speciális eljárási, illetve bizonyítási teherrel kapcsolatos szabályokat. Vizsgálatomban nagy segítséget nyújtott az Európai Jogi Akadémia által szervezett Anti-diszkriminációs kurzuson való részvétel is.

Összegezve tehát tanulmányomban röviden szót ejtek az egyenlő bánásmód követelményére vonatkozó szabályozásról, és bemutatni kívánom magának a követelményének a lényegét, a megsértési formáit, külön szólva a hátrányos megkülönböztetésről, illetve az egyenlő 
bánásmód megsértése alóli kimentés lehetőségéről, valamint a diszkriminációs ügyekben érvényesülő bizonyítási nehézségekről, és a bizonyítási teherről is szólok.

\section{Az egyenlő bánásmódra vonatkozó jogi szabályozás Uniós jog}

Az Uniós szabályozásról elmondhatjuk, hogy az egyenlő bánásmód elvének a követelménye az Unió gazdasági integrációja érdekében fogalmazódtak meg, és a kezdeti időszakban a négy fö szabadság hatékonyabb érvényesülése miatt deklarálták őket.

A római szerződés az egyenlő bánásmód elvét három tekintetben korlátozta:

- kizárólag a tagállamok polgáraival szembeni megkülönböztetést rendelte tiltani;

- kizárólag a nemek közötti diszkriminációt rendelte tiltani, a faj, kor, vallás, vagy éppen fogyatékosság alapján történő különbségtételt nem;

- a megkülönböztetés kizárólag a bérezés tekintetében minősült tiltottnak.[2]

A nők és férfiak egyenlő díjazásának elve már viszonylag hamar, a 75/117/EGK irányelvvel elfogadásra került, azonban például egészen az Amszterdami Szerződés elfogadásáig hiányzott a faj, kor, és vallás szerinti megkülönböztetés tilalma.

Az Európai Unió szabályozása kapcsán elmondható, hogy az elsődleges jog igen szűken szól az egyenlő bánásmód követelményéröl, melyre vonatkozó részletes szabályokat másodlagos jogforrások (irányelvek) szabályozzák.

A jelenlegi szabályozásból mindenekelőtt kiemelendő az Európai Unió Müködéséről Szóló Szerződés (a továbbiakban: EUMSz.) 18. cikke, melynek értelmében „A Szerződések alkalmazási körében és az abban foglalt különös rendelkezések sérelme nélkül, tilos az állampolgárság alapján történő bármely megkülönböztetés.” Az EUMSz. 45. cikkének (2) bekezdése alapján a munkavállalók szabad mozgása magában foglalja az állampolgárság alapján történő minden megkülönböztetés megszüntetését a tagállamok munkavállalói között a foglalkoztatás, a javadalmazás, valamint az egyéb munka- és foglalkoztatási feltételek tekintetében. A cikk (3) bekezdése azonban a közrendi, közbiztonsági vagy közegészségügyi okok alapján indokolt korlátozások bevezetésére ad jogi lehetőséget. Ugyanakkor a cikk rendelkezései nem vonatkoznak a közszolgálatban történő foglalkoztatásra.

$\mathrm{Az}$ elsődleges jog között érdemes megemlíteni az Európai Unió Alapjogi Chartáját[3], melynek 21. cikk (1) bekezdése rögzíti, hogy tilos minden megkülönböztetés, így különösen a nem, faj, szín, etnikai vagy társadalmi származás, genetikai tulajdonság, nyelv, vallás vagy meggyőződés, politikai vagy más vélemény, nemzeti kisebbséghez tartozás, vagyoni helyzet, születés, fogyatékosság, kor vagy szexuális irányultság alapján történő megkülönböztetés. A cikk (2) bekezdése szerint pedig a Szerződések alkalmazási körében és az azokban foglalt különös rendelkezések sérelme nélkül, tilos az állampolgárság alapján történő minden megkülönböztetés.

A Charta 23. cikke rendelkezik arról, hogy a nők és férfiak közötti egyenlőséget minden területen, így a foglalkoztatás, a munkavégzés és a díjazás területén is biztosítani kell. Az egyenlőség elve viszont nem akadályozza, hogy az alulreprezentált nem számára különleges előnyöket biztosító rendelkezéseket tartsanak fenn vagy hozzanak meg.

Elmondható, hogy a Lisszaboni Szerződés hatálybalépése óta megszaporodtak a hivatkozások az Alapjogi Charta különböző rendelkezéseire az Európai Bíróság joggyakorlatában.[4] Hozzá kell tenni, hogy a fótanácsnokok és az Európai Bíróság már a Charta kötelezővé válása előtt is hivatkoztak az Alapjogi Charta egyes rendelkezéseire különböző ügyekben. Mondhatni, mire a Charta jogi kötelező eröre emelkedett, a Chartára hivatkozás az uniós jog értelmezése során lényegében természetessé vált a Bíróság ítélkezési gyakorlatában. A Charta kötelezővé válása a Lisszaboni Szerződéssel azonban érzékelhető változásokat hozott a Bíróság hátrányos megkülönböztetéssel kapcsolatos gyakorlatában. Azt bizonyosan kijelenthetjük, hogy az Alapjogi Charta kötelezővé válása sokkal láthatóbbá tette 
és felerősítette az alapjogi alapú érvelést az ítélkezési gyakorlatban. A Chartára hivatkozás két csoportba sorolható. Az ügyek egy részében a Bíróság továbbra is az általános jogelvek mellett hivatkozik az Alapjogi Chartára. Ebbe a körbe lényegében a Kücükdeveci és Kristensen ügyek tartoznak. Az ügyek másik csoportjában a Bíróság autonóm, önálló jogforrásként használja az Alapjogi Chartát, gyakorlatilag mellőzve más nemzetközi dokumentumokra (különösen az Emberi Jogok Európai Egyezményére és az ahhoz kapcsolódó joggyakorlatra) vagy a tagállamok közös alkotmányos hagyományaira hivatkozást. A Chartára hivatkozás számos célt szolgál, így például a 2000/78/EK irányelv alóli kivételek megszorító értelmezésének alátámasztására, valamint a tagállamok mérlegelési mozgásterének szükítésére használja a Bíróság a 6. cikk (1) bekezdése alatt jogszerünek tekinthető intézkedések elfogadása során. Ebből két következtetés adódik: egyrészről a Bíróság kiemeli az Alapjogi Charta önálló jelentőségét a jogforrások között, másrészről a Charta kötelezővé válása ellenére is megmarad az általános jogelvek jelentősége a Bíróság ítélkezési gyakorlatában.[5]

Az egyenlő bánásmód követelményére vonatkozó fontosabb irányelvek pedig a következőek:

- 2000/43/EK irányelv a személyek közötti, faji- vagy etnikai származásra való tekintet nélküli egyenlő bánásmód elvének alkalmazásáról,

- 2000/78/EK irányelv a foglalkoztatás és a munkavégzés során alkalmazott egyenlő bánásmód általános kereteinek létrehozásáról,

- 2004/113/EK irányelv a nők és férfiak közötti egyenlő bánásmód elvének az árukhoz és szolgáltatásokhoz való hozzáférés, valamint azok értékesítése, illetve nyújtása tekintetében történő végrehajtásáról,

- 2006/54/EK irányelv a férfiak és nök közötti esélyegyenlöség és egyenlő bánásmód elvének a foglalkoztatás és munkavégzés területén történő megvalósításáról, valamint

- 2010/41/EU irányelv az önálló vállalkozói tevékenységet folytató férfiak és nők közötti egyenlő bánásmód elvének alkalmazásáról.

Ezek az irányelvek az általános kereteit adják meg az egyenlő bánásmód követelményének, így meghatározzák, hogy mely tulajdonságok alapján tilos a hátrányos megkülönböztetés, meghatározzák a hátrányos megkülönböztetés fogalmát, lehetőséget teremtenek bizonyos esetekben az eltérő bánásmód igazolására, rendelkeznek az egyenlő bánásmód követelményének megsértése történő hivatkozás esetén alkalmazandó bizonyítási teherről. Fontos kiemelni azonban, hogy ezek az irányelvek elsősorban a tagállamokra írnak elő olyan követelményeket, amelyeket az átültetés során kell megtartaniuk, és az irányelvben megjelölteknek megfelelő nemzeti szabályozást elfogadni. Így az irányelvekre történő magánszemélyek közötti jogvitában közvetlen hivatkozásra nem kerülhet sor.[6]

\section{Magyar szabályozás}

Az egyenlő bánásmód követelményének elve viszonylag fiatalnak mondható a magyar jogban, azonban a munkajog területén lényegében már az 1967-es szabályozásban megjelent, az 1992-es Mt.-ben pedig részletes szabályozást is kapott, a szabályozás irányvonala pedig összhangba került az Európai Uniós követelményekkel.[7]

A magyar szabályozás körében elsődlegesen az Alaptörvény az, amelynek XV. cikkének (2) bekezdése értelmében Magyarország az alapvető jogokat mindenkinek bármely megkülönböztetés, nevezetesen faj, szín, nem, fogyatékosság, nyelv, vallás, politikai vagy más vélemény, nemzeti vagy társadalmi származás, vagyoni, születési vagy egyéb helyzet szerinti különbségtétel nélkül biztosítja. A cikk (3) bekezdése szerint a nök és a férfiak egyenjogúak, míg a (4) bekezdés alapján Magyarország az esélyegyenlőség és a társadalmi felzárkózás megvalósulását külön intézkedésekkel segíti.

A Munka Törvénykönyvéről szóló 2012. évi I. törvény (a továbbiakban: Mt.) szintén igen szűken szól az egyenlő bánásmód követelményéröl, és teszi ezt kiemelve a munka 
díjazásával. Így az Mt. 12. §-ának (1) bekezdése szerint a munkaviszonnyal, így különösen a munka díjazásával kapcsolatban az egyenlö bánásmód követelményét meg kell tartani. $\mathrm{E}$ követelmény megsértésének orvoslása nem járhat más munkavállaló jogának megsértésével vagy csorbításával. A 12 . $\S$ további rendelkezései pedig a munkabér fogalmát, és a munka egyenlő értékének meghatározását adják meg.

A fentebb megjelölt Uniós irányelvi követelményeknek történő megfelelésre került elfogadásra az egyenlő bánásmódról és az esélyegyenlőség előmozdításáról szóló 2003. évi CXXV. törvény (a továbbiakban: Ebktv.), amely részletesebb és pontosabb szabályozást határoz meg az egyenlő bánásmód követelményével kapcsolatban. Rendelkezik arról, hogy az egyenlö bánásmód követelményét mely jogviszonyokban kell betartani: a törvény 5 . §-ának d) pontja alapján az egyenlő bánásmód követelményét az adott jogviszony tekintetében köteles megtartania munkáltató a foglalkoztatási jogviszony, az utasításadásra jogosult személy a munkavégzésre irányuló egyéb jogviszony, illetve az ezekkel közvetlenül összefüggő jogviszonyok tekintetében. Az Ebktv. szól az egyenlő bánásmód megsértési formáiról is: a hátrányos megkülönböztetésről (közvetlen, közvetett), a zaklatásról, a jogellenes elkülönítésről, és a megtorlásról.

Az Ebktv. bevezette az egyenlő bánásmód követelményét a hátrányos megkülönböztetés tilalma helyett. Ez azonban lényegi változást is eredményezett, mert meghatározta az egyenlő bánásmód követelménye megsértésének minősül öt magatartást: közvetlen és közvetett hátrányos megkülönböztetés, zaklatás, jogellenes elkülönítés, valamint megtorlás. További jelentősége, hogy a törvényben meghatározott egyenlő bánásmód elve valamennyi jogágra hatással van, mivel a külön jogszabályokban meghatározott antidiszkriminációs rendelkezéseket ezzel összhangban kell alkalmazni.[8]

$\mathrm{Az}$ egyenlő bánásmód követelményének megsértését jelenti a közvetlen hátrányos megkülönböztetés, a közvetett hátrányos megkülönböztetés, a zaklatás, a jogellenes elkülönítés, a megtorlás, valamint az ezekre adott utasítás (Ebktv. 7. §-ának (1) bekezdése). Ebböl a felsorolásból látszólag az következik, hogy csak az felsorolt fogalmakat sértő magatartások, rendelkezések ütköznek az egyenlö bánásmód követelményébe. A 7. § azonban hozzáteszi a felsoroláshoz azt is, hogy „különösen a III. fejezetben meghatározottak szerint”. Következésképpen nem kizárólag az Ebktv. III. részében meghatározott tilalmakba ütköző magatartás sértheti az egyenlő bánásmód követelményét, hanem más jogszabályok is meghatározhatnak ilyen magatartást. Ezt megerősíti, hogy az egyenlő bánásmód követelményére vonatkozó, külön jogszabályokban meghatározott rendelkezéseket az Ebktv. rendelkezéseivel összhangban kell alkalmazni (Ebktv. 2. §). Az Ebktv. alkalmazását tehát nem szűkítették le az abban szereplő szabályokra, hanem kiterjesztették a jogrendszer egészében szereplő antidiszkriminációs szabályok alkalmazására.[9]

Az Ebktv. 21. §-a a foglalkoztatás körében meghatározza azokat a területeket, ahol az egyenlő bánásmód követelményét be kell tartani.

Az Ebktv. 22. §-ának (1) bekezdése rendelkezik arról is, hogy nem jelenti az egyenlő bánásmód követelményének megsértését

a) a munka jellege vagy természete alapján indokolt, az alkalmazásnál számba vehető minden lényeges és jogszerű feltételre alapított arányos megkülönböztetés,

b) a vallási vagy más világnézeti meggyőződésen, illetve nemzeti vagy etnikai hovatartozáson alapuló, a szervezet jellegét alapvetően meghatározó szellemiségből közvetlenül adódó, az adott foglalkozási tevékenység tartalma vagy természete miatt indokolt, arányos és valós foglalkoztatási követelményen alapuló megkülönböztetés.

A (2) bekezdés pedig meghatározza, hogy a 21. §-ának $f$ ) pontja alkalmazása során a 8 . $§ a$ )e) pontjaiban meghatározott tulajdonság tekintetében tett közvetlen hátrányos megkülönböztetés minden esetben sérti az egyenlö bánásmód követelményét. 


\section{Az egyenlő bánásmód követelménye és megsértésének módjai}

Az egyenlö bánásmód követelményére vonatkozóan azt mondhatjuk, hogy az megköveteli a természetes személyekkel, ezek csoportjaival, valamint a jogi személyekkel és a jogi személyiséggel nem rendelkező szervezetekkel szemben az azonos tisztelettel és körültekintéssel, az egyéni szempontok azonos mértékű figyelembevételével történő eljárást.[10]

Az Európai Bíróság gyakorlatában ezen elv olyan íratlan közösségi jogelv, amely tartalma lényegét tekintve azonos tényállásokat tilos különbözőképpen, az egymástól eltérő tényállásokat tilos azonos módon kezelni.[11]

Az egyenlö bánásmód követelményét akként is definiálhatjuk, hogy az megfelel a közvetlen hátrányos megkülönböztetés és a közvetett hátrányos megkülönböztetés tilalmának.[12]

Összegezve az egyenlő bánásmód elve alatt tehát azt érthetjük, hogy személyek vagy személyi csoportok között nem lehet indokolatlanul különbséget tenni. A jogi szabályozás fö kérdése pedig az, hogy mi minősül indokolatlan különbségtételnek, ki köteles megtartani az egyenlő bánásmód követelményét, illetve annak megsértése hogyan szankcionálható.

Azon túl, hogy az egyenlő bánásmód egy globális követelmény, szektoriálisan is jelentkezik. A munkaviszony kevés olyan magánjogi jogviszonyok közé tartozik, ahol a jogviszony teljes tartama alatt érvényesül.[13]

A követelmény megsértése módjainak alábbi bemutatása során elkülönülten vizsgálom az Uniós szabályozás által meghatározott formákat, majd pedig a magyar szabályozásban megjelenőekre térek át.

\section{Az Uniós szabályozásban megjelenő megsértési formák}

Elmondható, hogy az Uniós jogban eredetileg a „diszkrimináció” kifejezésnek csak egy jelentése létezett, amely magában foglalta a külön nevesített, és tiltott feltételeken alapuló, összehasonlítható helyzetben lévő személyek egyenlőtlen bánásmódját.[14] Később az Európa Bíróság kifejlesztett egy további jogi fogalmat, a közvetett hátrányos megkülönböztetést, és megfogalmazta a különbségtételt a közvetlen és közvetett diszkrimináció között. (lásd pl.: C170/84. Bilka, C-237/94. O’Flynn ügyek) Utóbb ezt alapul véve került az irányelvekben rögzítésre az egyenlő bánásmód megsértésének a négy megnyilvánulási formájából három, nevezetesen a közvetlen és közvetett diszkrimináció, valamint a zaklatás. A megkülönböztetésre adott utasítás megjelenik ugyan a 2000/43/EK irányelv 2. cikkének (4) bekezdésében, de fogalma nincs megadva.[15]

Ezen bevezetést követően részletesebben térnék ki az egyes megsértési formák bemutatására azzal, hogy a közvetlen vagy közvetett hátrányos megkülönböztetés vonatkozásában csak érintőlegesen beszélek, azokat külön fejezetben részletezem.

Közvetlen hátrányos megkülönböztetés: akkor áll fenn, ha egy személy egy másikhoz képest kedvezőtlenebb ellátásban részesül, részesült, vagy fog részesülni egy hasonló helyzetben a meghatározott okok (vallása, meggyőződése, fogyatékossága, életkora, szexuális irányultsága) bármelyike alapján.[16] Továbbá közvetlen megkülönböztetés áll fenn, ha egy személlyel szemben faji vagy etnikai alapon kevésbé kedvezően járnak el, mint ahogyan egy másik személlyel szemben hasonló helyzetben eljárnak, eljártak, vagy eljárnának.[17]

Közvetett hátrányos megkülönböztetés: akkor áll fenn, ha egy látszólag semleges rendelkezés, feltétel, vagy gyakorlat egy bizonyos vallású, vagy meggyőződésü, egy bizonyos fogyatékosságú, egy bizonyos életkorú vagy egy bizonyos szexuális irányítottságú, vagy egy faji vagy etnikai származású személyeket más személyekkel szemben hátrányos helyzetbe hoz/ más személyekhez képest különösen hátrányosan érint.[18]

Zaklatás: a meghatározott tulajdonságokhoz kapcsolódó nem kívánt magatartás azzal a céllal vagy hatással történik, hogy egy személy méltóságát megsértse, és megfélemlítő, ellenséges, megalázó, megszégyenítő (lekicsinylő) vagy támadó környezetet alakítson ki.[19] Itt 
említendő meg, hogy a nemek közötti egyenlőségre vonatkozó szabályozás további különbséget tesz zaklatás és szexuális zaklatás között.

A zaklatás tipikus esete a védett tulajdonságokon alapuló munkahelyi megfélemlítés, amely megnyilvánulhat szóban, tettekben, vagy lelki stressz okozásában is.[20] Zaklatás valósul meg továbbá a munkatársaktól történő elszigeteléskor, a beszélgetésekből vagy feladatokból történő kizárással, rosszindulatú pletyka híresztelésével.[21] Zaklatásnak minősül az is, ha a sérelmet szenvedett által a vele szembeni rossz bánásmód miatt előterjesztett hivatalos panasszal nem foglalkoztak megfelelően, rá és a gyermekére vonatkozóan illetlen és sértő megjegyzéseket tettek.[22]

Az Európai Bíróság az ún. Coleman ügyben (C-303/06.) fogalmazta meg azt, hogy amennyiben bizonyítást nyer, hogy valamely nem fogyatékos munkavállalót nemkívánatos magatartással folyamatosan zaklatnak, és e zaklatás a munkavállaló gyermekének fogyatékosságán alapul, akinek a gondozását a munkavállaló nagyrészt maga végzi, az ilyen magatartás sérti a 2000/78 irányelvet és különösen a 2. cikkének (3) bekezdésében elöírt zaklatás tilalmát. E tekintetben azonban tekintettel kell lenni arra, hogy ezen irányelv 2. cikke (3) bekezdésének szövege szerint a zaklatás fogalmát a tagállamok nemzeti jogukkal és gyakorlatukkal összhangban határozhatják meg. Az alapügyben felmerülthez hasonló helyzetben a bizonyítási teherre vonatkozó szabályokat illetően hangsúlyozni kell, hogy mivel a zaklatás a 2000/78 irányelv 2. cikkének (1) bekezdésében vett hátrányos megkülönböztetés egy formájának minősül, a zaklatásra ugyanazon szabályok alkalmazandók, mint amelyek a jelen ítélet 5255. pontjában kifejtésre kerültek.[23]

Megkülönböztetésre adott utasítás: mint fentebb említettem, jogszabályban meghatározott definíciója nincs. A bírói gyakorlat alapján azt a helyzetet jelenti, amikor egy személyi utasítás ad lehetőséget harmadik személlyel szemben a közvetlen vagy közvetett hátrányos megkülönböztetés, vagy a zaklatás alkalmazására.[24]

\section{A magyar szabályozásban megjelenő megsértési formák}

A magyar szabályozásban az Ebktv. az, amely meghatározza az egyenlő bánásmód követelményének megsértési módjait, azzal hogy az uniós szabályokhoz képest a jogellenes elkülönítést és a megtorlást is az egyenlő bánásmód követelményének megsértése közé sorolja. Fontos megemlíteni, hogy az uniós szabályokhoz képest a védett tulajdonságok sokkal szélesebb körben kerültek meghatározásra, és az „egyéb helyzet, tulajdonság vagy jellemző" kitétellel szinte bármely okra történő hivatkozást lehetővé tett a magyar jogalkotó. A közvetlen vagy közvetett hátrányos megkülönböztetés, és a zaklatás fogalma meghatározásában azonban jelentős eltérés nincs. A törvény lényegében az irányelvekben meghatározott fogalmakat használja azonos tartalommal.

Látszólag különböző magatartásokat tiltanak az Ebktv.-ben (közvetlen, közvetett hátrányos megkülönböztetés, zaklatás, jogellenes elkülönítés, megtorlás) és az egyéb jogszabályokban (akadálymentesítési kötelezettség, egyenlő bér elve) található fogalmak.

Valójában az Ebktv. két tilalmat részletez, a közvetlen és a közvetett hátrányos megkülönböztetést. A zaklatás, a jogellenes elkülönítés, a megtorlás, az akadálymentesítés elmulasztása és az egyenlő bér elvének megsértése egyaránt a közvetlen hátrányos megkülönböztetés speciális esetei.

A fogalmak „osztódása” egyrészt a közösségi jogi követelményeknek köszönhető, amelyek kötelezték a magyar jogalkotást a közvetlen és a közvetett hátrányos megkülönböztetés, az egyenlő bér elve, a zaklatás, a szexuális zaklatás és a megtorlás fogalmának meghatározására. Másrészt, az akadálymentesítési kötelezettség és a jogellenes elkülönítés tilalmának részletes meghatározása nem a közösségi jogból következik, hanem az alkotmányos jogok hatékonyabb érvényesülését célozza. Ezek tehát valójában nem külön fogalmak, hanem a közvetlen hátrányos megkülönböztetés esetei, de külön történő meghatározásuk hozzájárulhat az ilyen jogsértésekkel szembeni eredményes fellépéshez.[25] 


\section{A hátrányos megkülönböztetés két fajtája és fennállásának kritériumai}

Mint már fentebb említettem, a jogi szabályozás a hátrányos megkülönböztetésnek két fajtáját ismeri: a közvetlen és a közvetett hátrányos megkülönböztetést, valamint az Uniós és a magyar jogszabályok a hátrányos megkülönböztetés e két formájának meghatározásában jelentős eltérést nem mutatnak. Ebben a fejezetben elöször megpróbálom elhatárolni egymástól a diszkrimináció e két formáját, majd külön-külön szólok azok fennállásának a feltételeiröl.

A közvetlen diszkrimináció megkülönböztetése és elhatározása a közvetett diszkriminációtól alapulhat magának a hátrányos megkülönböztetésnek a természetéböl, valamint a kimentés oldaláról is. Bár szoros kapcsolatban állnak egymással, eltérő jogi fogalmak, amely hatással van a gyakorlati alkalmazásukra is (bizonyítás, kimentési lehetőség). [26]

A hátrányos intézkedés természetének oldaláról vizsgálva formája és tartalma szerint megkülönböztetve a közvetlen és közvetett diszkriminációt, azt mondhatjuk, hogy:

- az intézkedés külső megjelenése lehet: vagy kifejezetten hátrányos, vagy látszólag semleges,

- míg az intézkedés hatása szerint lehet: a hátrány egy csoporton belül, azok tagjainál jelenik meg, (beleértve azokat az eseteket is, amikor ez a hátrány vagy természetileg, vagy jogszabályon alapuló elöírás eredménye), illetve a hátrány két csoportban lévő személyeknél jelenik meg, de a személyek egy bizonyos csoportját különösen hátrányos helyzetbe hozza.

A hátrányos intézkedés kimentési oldaláról vizsgálva pedig a hátrányos intézkedés objektíve igazolhatósága a közvetlen diszkrimináció esetében nem lehetséges, az kizárólag a közvetett diszkriminációnál merülhet fel.

A közvetlen diszkrimináció megállapításához szükséges, hogy az érintett: meghatározott tulajdonság, vagy ok miatt; kedvezőtlenebb bánásmódban részesül, részesült, részesülni fog, és szükséges egy összehasonlítható helyzet fennállása.[27]

1. Meghatározott tulajdonság, vagy ok

Mind az Uniós, mind a magyar szabályozás megjelöli azokat a védett tulajdonságokat, okokat, amelyek alapján tilos a hátrányos megkülönböztetés. Ezek többségében egyértelmủek, azonban néhány tulajdonság vonatkozásában az Európai Bíróság és a magyar bíróságok előtt is merült fel probléma. Tanulmányomban ezekre helyezem inkább a hangsúlyt.

- fogyatékosság: ez alatt a fogyatékos személyek jogairól és esélyegyenlőségük biztosításáról szóló 1998. évi XXVI. törvény 4. §-ának a) pontjában meghatározott fogyatékos személyt kell érteni. Így például nem vonható ebbe a körbe az alkoholfüggőség, valamint a tartós betegség sem.[28] A „fogyatékosság” további fogalma olyan korlátozottságként értendő, amely különösen valamilyen testi, szellemi vagy lelki ártalmon alapul, és az érintettet akadályozza a szakmai életben való részvételben.[29] A fogyatékosságra azonban nem csupán az a személy hivatkozhat, aki maga fogyatékos, hanem az is, akinek gyermeke (hozzátartozója) fogyatékos és, akinek a gondozását nagyrészt maga végzi.[30]

- egészségi állapot: a keresőképtelen állapot ebben a körben értékelhető, és akár már egy hetes munkából történő kiesés esetén is hivatkozási alap lehet. Az egészségi állapot azonban egyénhez kötött, ezért szemben a fogyatékossággal, itt nem hivatkozhat az, akinek hozzátartozója beteg.

- egyéb ok:[31] az erre történő hivatkozás esetén is konkrétan meg kell jelölni valamilyen tulajdonságot, amelynek a személyiség lényegi vonásához kell kapcsolódnia. Az Egyenlő Bánásmód Tanácsadó Testülete 288/2010. (IV.9.) állásfoglalása értelmében az „egyéb helyzet, tulajdonság" nem azonos az elszenvedett hátránnyal, az nem lehet csak egy 
személynél előforduló tulajdonság. Így például a Kúria (korábban Legfelsőbb Bíróság) elfogadta hivatkozásként a külső fizikai megjelenést, az iskolai végzettséget, a szülő párt világnézettségét, a szexuális alapú közeledés elutasítást, a munkavállaló kölcsönvett voltát, vagy azt, hogy egy másik álláshelyre jelentkezett. Az Egyenlö Bánásmód Hatóság egy zaklatást megállapító határozatban[32] egyéb helyzetnek tekintette azt a körülményt, hogy a kérelmező a munkáltatóval szemben munkaügyi, illetve büntető pereket nyert, valamint az igazgatónál magasabb iskolai végzettség megszerzése érdekében továbbtanult. Semmiképpen nem vonható ebbe a körbe a lakó- illetve tartózkodási hely, a felettessel történő megromlott viszony, megbízási szerződéssel történő foglalkoztatás, a hátrányos megkülönböztetést megvalósító magatartásként meghatározott megtorlás,[33] vagy az, ha az érintettnek nem volt kapcsolati tőkéje.

\section{Kedvezőtlenebb bánásmód}

Bánásmód alatt érthetünk állásajánlatot, munkabért, prémium elmaradását, vagy kevesebb összegű prémiumot, előrelépési lehetőséget, munkáltatói megrovást, vagy figyelmeztetést, értékelést, feladatok átruházását, munkavégzési feltételeket (kafatéria juttatás, céges autó, titkárnő) vagy a munkaviszony megszüntetését.

Kedvezőtlenebb a bánásmód, ha az érintettet hátrányosan érinti.

\section{Részesül, részesült, részesülni fog kifejezések értelmezése}

A részesül, részesült, részesülni fog kitételek vonatkozásában elmondható, hogy elég egyértelmüen értelmezhetők, hiszen a munkaviszony megszüntetése esetén az érintett a kedvezőtlenebb bánásmódban már részesült, az alacsonyabb bér esetén pedig részesül. A részesülni fog kitétellel kapcsolatban mindazonáltal maga az Európai Bíróság is megállapította, hogy ,a társadalmi integrációt szolgáló munkaerőpiac feltételei elősegítésének célja nehezen lenne elérhető, ha a 2000/43 irányelv hatálya kizárólag azon esetekre korlátozódna, amelyekben egy felvételt nem nyert jelölt - aki állítása szerint közvetlen hátrányos megkülönböztetés áldozata - bírósági eljárást indít a munkáltatóval szemben.” „...Az ilyen közvetlen hátrányos megkülönböztetés fennállásának nem feltétele, hogy azonosítható legyen egy sértett személy, aki állítása szerint ilyen hátrányos megkülönböztetésnek vált áldozatává.” [34]

\section{4. Összehasonlítható helyzet}

Az érintettnek összehasonlítható helyzetben kell lennie, amely különösképpen azt feltételezi, hogy a munkavégzés lényeges vonalaiban kell hasonló helyzetben lennie.

Főszabály szerint az adott szervezeti egységben dolgozó munkavállalókat kell vizsgálni,[35] és az ő helyzetükkel összehasonlítani az érintettet, azonban bizonyos esetekben indokolt lehet a munkáltatónál foglalkoztatott valamennyi munkavállalót vizsgálni[36] (Pl.: országos rendőri állomány, nemcsak a BRFK, a MÁV országos állománya, nem csak egy területi igazgatósága).

Továbbá a bírói gyakorlat szerint például létszámcsökkentés esetén, azokkal a személyekkel kell összehasonlítani, akiket nem bocsátottak el. A kirendelt munkavállalókat nem lehet összehasonlítani a saját munkavállalókkal, továbbá a különböző jogviszonyban lévő munkavállalók sem hasonlíthatóak össze a munkabér vonatkozásában.

A közvetett diszkrimináció ezzel szemben azt követei meg, hogy az érintett meghatározott tulajdonság, vagy ok miatt látszólag semleges rendelkezés, feltétel, gyakorlat alapján részesül, részesült, részesülni fog kedvezőtlenebb bánásmódban.[37]

A látszólag semleges rendelkezés első olvasásra az egyenlő bánásmód követelményének megfelel, azonban hatása mégis az, hogy hátrányos helyzetbe hoz. Ilyen lehet az olyan általános munkaidő meghatározása, amely hátrányosan érinti a kisgyermekes 
munkavállalókat, vagy prémium kikötése abban az esetben, ha a munkavállaló az értékelési időszak teljes idejét munkában tölti, és nem vesz ki szabadságot, betegszabadságot. Maga a rendelkezés pedig lehet jogi előírás, jogi szabályozás egyéb formája, kollektív szerződés, szokásos üzleti gyakorlat, munkaerő-kölcsönzési szerződés, valamint a rendelkezés lehet a munkaszerződés része is. A feltétel alatt érthetjük a foglalkoztatáshoz kapcsolódó döntési tényezö(ke)t (pl.: felvételnél, elörelépési lehetőségnél). A gyakorlat pedig lehet egy konkrét gyakorlat, beleértve a rendelkezés, feltétel alkalmazását is.

\section{Kimentés}

Az egyenlő bánásmód követelményének vizsgálata során szólnunk kell azokról az esetekről, amikor a követelmény megsértése megtörténik ugyan, azonban a jogszabályban meghatározott feltételek esetén azt mégsem lehet az egyenlö bánásmód követelményének megsértéseként minősíteni. Azok a területek, ahol az eltérő bánásmód elfogadott, illetve elvárt, külön kerülnek meghatározásra mind az Uniós irányelvekben, mind az Ebktv.-ben.

Az eltérő bánásmód alapulhat egyrészt, mint lehetőségen másrészt, mint kötelezettségen.[38]

Elöbbi körébe tartoznak:

- a foglalkozási követelmények (2000/43/EK és 2000/78/EK rendelet 4. cikke),

- a pozitív intézkedések (2000/43/EK 5. cikke és 2000/78/EK rendelet 7. cikke),

- a közbiztonság, a közrend fenntartásához, a büncselekmények megakadályozásához, az egészség védelméhez és mások jogainak és szabadságának a védelme (2000/78/EK rendelet 2. cikk (5) bekezdése), valamint

- az objektíve igazolhatóság esete (2000/78/EK rendelet 6 . cikke).

Utóbbiba pedig a 2000/78/EK irányelv 5. cikkében meghatározott fogyatékos személyek igényeihez való ésszerü alkalmazkodás körében elöírt intézkedések megtétele, mint tagállami kötelezettség tartozik.

\section{Az Uniós irányelvekben megfogalmazott kimentési lehetőség}

Az Uniós irányelvek, ahogy azt korábban már említettem, a tagállamok számára írják elő az egyenlő bánásmód követelményének betartását. Így a tagállamok kötelezettsége a foglalkoztatásra és a munkavégzésre vonatkozó szabályok során az egyenlő bánásmód követelményének az érvényre juttatása, olyan jogszabályok alkotása, amelyek biztosítják az elv hatékony érvényesülését. Azonban az Uniós jog bizonyos feltételek esetén mégis lehetővé teszi a tagállamoknak az eltérő bánásmódra vonatkozó szabályok megalkotását. Az Európai Bíróság esetjogában az irányelvek szerinti kimentést három különböző alapon fogalmazta meg:[39]

1. a 2. cikk (5) bekezdése szerinti,

2. a 4. cikk (1) bekezdése szerinti,

3. a 6 . cikk (1) bekezdése szerinti.

Mindezeken felül további követelményként került megfogalmazásra az Európai Bíróság gyakorlatában az, hogy a tagállami intézkedésnek az irányelvben megjelölt célok alapján igazoltnak, a célok elérése érdekében alkalmasnak, valamint szükségesnek kell lennie.

A Bíróság gyakorlata alapján továbbá megállapítható, hogy kimentési lehetőség előírható:

- a munkaszerződés megkötése elötti eljárásra (pl.: a felvétel maximum életkorhoz kötése),

- a munkaszerződés alatt (pl.: életkor szerint bérezés, illetve szabadság), valamint

- a munkaszerződés utánra (pl.: felmondási idő).[40]

Annak megítélése során, hogy egy adott tagállami intézkedés megfelel-e a megjelölt céloknak, az Európai Bíróság gyakorlata adhat támpontot, mely igazolt célnak minősítette többek között a következőket:

- a 2. cikk (5) bekezdése vonatkozásában: a légiközlekedés biztonsága[41]

- a 4. cikk (1) bekezdése vonatkozásában: a hivatásos tüzoltóság müködőképességének és megfelelő müködésének biztosítása[42] 
- a 6. cikk (1) bekezdése vonatkozásában: a foglalkoztatás elősegítése,[43] a munkaerő-piaci politika,[44] gazdasági, szociális vagy demográfiai politika,[45] szakképzési politika.[46] A tagállami rendelkezés alapján továbbá azt kell vizsgálni, hogy az ilyen jogszerü cél elérésének eszközei megfelelőek-e. Az intézkedés alkalmas volta körében például a Bíróság nem találta megfelelőnek az olyan rendelkezést, amely egyenlötlenül érinti a fiatal munkavállalókat, mivel sújtja azokat a fiatalokat, akik korán válnak keresővé szakképzettség nélkül vagy rövid szakképzést követően -, és nem sújtja azokat, akik később, hosszú képzést követően kezdenek el dolgozni.[47]

Az intézkedés szükségességével kapcsolatban pedig elmondhatjuk, hogy annak vizsgálata során az intézkedést a hátterét képező szabályozási környezetbe kell helyezni, és figyelembe kell venni mind az érintett személyeknél várhatóan bekövetkező hátrányt, mind pedig azokat az elönyöket, amelyekben általában véve a társadalom és az azt alkotó egyének részesülnek.[48]

Továbbá, figyelemmel arra, hogy a diszkrimináció tilalmazott formáinak köre nem állandó, az, hogy a megkülönböztetés mely konkrét formái minösülnek elfogadhatatlannak egy adott kor társadalmi, gazdasági, politikai felfogását tükrözi és a társadalommal együtt fejlődik.[49]

\section{Az Ebktv. kimentési lehetősége}

Az Ebktv. 7. § (2) bekezdése alapján az olyan magatartás, intézkedés, feltétel, mulasztás, utasítás vagy gyakorlat (a továbbiakban együtt: rendelkezés) nem sérti az egyenlő bánásmód követelményét,

a) amely a hátrányt szenvedő fél alapvető jogát másik alapvető jog érvényesülése érdekében, elkerülhetetlen esetben korlátozza, feltéve, hogy a korlátozás a cél elérésére alkalmas és azzal arányos,

b) amelynek az a) pont hatálya alá nem tartozó esetekben tárgyilagos mérlegelés szerint az adott jogviszonnyal közvetlenül összefüggö, ésszerü indoka van.

A (3) bekezdés szerint azonban az Ebktv. 8. § b)-e) pontja szerinti tulajdonságon alapuló közvetlen hátrányos megkülönböztetés, valamint jogellenes elkülönítés esetében a (2) bekezdés nem alkalmazható, így az minden esetben az egyenlő bánásmód megsértését jelenti.

A kialakult bírói gyakorlat szerint a hátrányos megkülönböztetés akkor megengedett, ha az összefügg a munkaviszonnyal, valamint a munka jellegéből vagy természetéből egyértelmüen következik. Ilyennek minősül különösen az alkalmazásnál számba vehető minden lényeges és jogszerü feltételre alapított megkülönböztetés.[50] A munka díjazása tekintetében minden olyan megkülönböztetés megengedett, amely a munkát végző személy széles értelemben vett munkavégzéséhez, a jogviszonyból eredő kötelezettségei teljesítéséhez kapcsolódik.[51] Végül abban az esetben, ha a megkülönböztetés szükséges, illetve objektív tényezőkkel indokolható, a megkülönböztetés nem minősül tiltottnak (ilyen lehet például női öltözőben női felügyelő alkalmazása).[52]

\section{Bizonyítási teher az egyenlő bánásmód megsértése esetén}

A diszkriminációs ügyekben a sérelmet szenvedett fél számára kedvezőbb bizonyítási eljárás alkalmazását teszi lehetővé a jogi szabályozás. Így a 2000/78/EK irányelv 10. cikkének (1) bekezdése arról rendelkezik, hogy a tagállamok nemzeti igazságszolgáltatási rendszerüknek megfelelően megteszik a szükséges intézkedéseket annak érdekében, hogy biztosítsák, azok a személyek, akik úgy érzik, hogy az egyenlő bánásmód elve alkalmazásának elmulasztása miatt őket sérelem érte, bíróság vagy más illetékes hatóság előtt olyan tényekre hivatkozhassanak, amelyek alapján feltételezhető, hogy közvetlen vagy közvetett hátrányos megkülönböztetés történt. Ekkor az alperes kötelessége annak bizonyítása, hogy nem sértette meg az egyenlő bánásmód elvét.

Fentiekből következően, amikor hátrányos megkülönböztetés esetének alapos gyanúja merül fel, a bizonyítási teher általános szabályai megváltoztathatóak. Az egyenlő bánásmód elvének 
hatékony alkalmazása érdekében ugyanis a bizonyítási teher visszaszáll az alperesre, abban az esetben, ha a hátrányos megkülönböztetés bizonyított.

Azonban fontos kiemelni, hogy nem az alperes feladata annak bizonyítása, hogy a felperes egy bizonyos tulajdonsággal rendelkezik.

A diszkriminációs ügyekben egy ún. három lépcsős elemzés segítségével dönthetjük el, az adott esetben történt-e hátrányos megkülönböztetés.[53]

A kiindulási pont az, hogy a bánásmód (általános szabály vagy egyedi munkáltatói döntés) a diszkrimináció lehetőségét hordozza. Tehát három kérdéskör vizsgálandó:

1. Az adott ügy a nemzeti vagy az Uniós anti-diszkriminációs jogszabályok hatálya, illetve alkalmazási területe alá tartozik-e? Azaz a sérelmet szenvedett foglalkoztatásával összefüggésben áll-e? Ennek során vizsgálandó például a támadott intézkedés mibenléte, az a munkáltatótól származik-e, összefüggésben van-e a munkaviszonnyal. Megjegyezendő, hogy a hatály vizsgálata során vannak egyértelmü esetek (pl.: az intézkedés a munkabért érinti), azonban vannak kérdéses ügyek, amikor az eset összes körülményei alapján elemezni kell, hogy például az adott intézkedés a díjazás fogalmába tartozik-e, a munkaviszonyra tekintettel került-e sor az elfogadására, illetve munkaszerződés vagy kollektív szerződés teremtett-e lehetőséget az elfogadására.[54]

2. Történt-e (első látásra) diszkrimináció? (azaz közvetlen, közvetett hátrányos megkülönböztetés, zaklatás, illetve megkülönböztetésre adott utasítás) Ebben a körben a fentebb részletezetteknek megfelelően kell vizsgálni, hogy a támadott intézkedés valóban megvalósít-e diszkriminációt, avagy sem.

3. Van-e kimentés? (pl.: törvényes eltérésre lehetőség, vagy objektív igazolás) Fennállhatnak olyan esetek, amikor valóban történt eltérö bánásmód, azonban arra azért került sor, mert az intézkedést hozó nem volt köteles megtartani azt, illetve lehetősége volt az eltérö bánásmód alkalmazására.

A bizonyítási teher a gyakorlatban úgy néz ki, hogy a felperes megalapozza a tényeket, amelyekböl az feltételezhetö, hogy közvetlen/közvetett hátrányos megkülönböztetés történt, majd ezt követően a bizonyítás terhe átkerül az alperesre.[55]

Probléma merülhet fel azonban abban az esetben, ha a felperes nincs azoknak a bizonyítékoknak a birtokában, amelyekből egyértelmüen hivatkozhatna az egyenlő bánásmód követelményének megsértésre. Az Európai Bíróság a C- 104/10. számú ügyében akként foglalt állást ezen kérdésben, hogy főszabály szerint ha az alperes az ilyen tények bizonyítása keretében megtagadja az információnyújtást, ez veszélyeztetheti az irányelv céljának megvalósítását, ezáltal pedig megfoszthatja többek között az irányelv 4. cikkének (1) bekezdését a hatékony érvényesülésétől. Azonban a 76/207 irányelv 4. cikkének, illetve a 2002/73 irányelv 1. cikke 3. pontjának megfogalmazásából nem következik, hogy a felperesnek joga lenne hozzáférni az alperes birtokában lévő, a többi munkavállalóval, illetve fel nem vett személlyel kapcsolatos információkhoz, mivel a hozzáférési jogot korlátozhatják többek között például a bizalmas kezelésre vonatkozó uniós jogszabályok.[56]

Minden esetben a nemzeti bíróság feladata ügyelni arra, hogy a közvetlen vagy közvetett hátrányos megkülönböztetés fennállására következtetni engedő tények megállapításakor a felvilágosítás adásának a munkáltató általi megtagadása ne veszélyeztesse a 2000/43, a 2000/78 és a 2006/54 irányelv célkitüzéseinek megvalósítását. A bíróság feladata többek között a jogvita összes körülményének figyelembe vétele, annak eldöntése érdekében, hogy kellő bizonyíték áll-e rendelkezésre ahhoz, hogy az ilyen hátrányos megkülönböztetés fennállásának vélelmezését lehetővé tevő tényeket bizonyítottnak lehessen tekinteni.[57] Fentiekből következően tehát azt mondhatjuk, hogy abban az esetben, amikor a felperes nincs azoknak a tényeknek a birtokában, amelyekből következtethető lenne az egyenlő bánásmód követelményének megsértése, az alperes ezen adatok szolgáltatására föszabály szerint kötelezhető, azaz köteles azokat a felperes rendelkezésére bocsátani. Azonban lehetnek olyan 
jogszabályi (akár Uniós, akár nemzeti) rendelkezések, amelyek ezt az információhoz való hozzáférést korlátozhatják, illetve kizárhatják.

A bizonyításra vonatkozó magyar szabályok a következőképpen szólnak: A Polgári perrendtartásról szóló 1952. évi III. törvény (a továbbiakban: Pp.) 3. § (3) bekezdése alapján a jogvita elbírálásához szükséges bizonyítékok rendelkezésre bocsátása - ha törvény eltérően nem rendelkezik - a feleket terheli. A bizonyítás indítványozása elmulasztásának, illetve a bizonyítási indítvány elkésett voltának jogkövetkezményei, valamint a bizonyítás esetleges sikertelensége törvény eltérő rendelkezése hiányában a bizonyításra kötelezett felet terheli.

A Pp. 164. § (1) bekezdése szerint a per eldöntéséhez szükséges tényeket általában annak a félnek kell bizonyítania, akinek érdekében áll, hogy azokat a bíróság valónak fogadja el.

Főszabály szerint tehát a polgári (és munkaügyi) perekben a feleknek bizonyítaniuk kell, hogy az általuk hivatkozott tények valósak. Azonban a diszkriminációra történő hivatkozás esetén a felperesnek elegendő valószínűsítenie azt a tényt, hogy öt hátrányos megkülönböztetés érte. Ebben a körben viszont a Pp. 3. § (3) bekezdése alapján a felperesnek meg kell jelölnie a védett tulajdonságot, azt a hátrányt, amely öt érte, valamint egy összehasonlítható csoportot, és a továbbiakban a Pp. 164. §-a szerint kell bizonyítani azt, amit a perben állít.

Így a következőek vizsgálandók:

1. A felperes hivatkozik-e az Ebktv.-ben meghatározott védett tulajdonságok közül valamelyikére?

2. Valóban érte-e hátrány?

3. A felperes határoz-e meg összehasonlítható csoportot, illetve van-e összehasonlítható csoport?

A bizonyítási teherre vonatkozó szabályok az Ebktv. 19. §-a és a Pp. 164. § (1) bekezdés szerinti eltérő szabályok veendők figyelembe. Ezen munkavállalóra kedvező bizonyítási teherre tekintettel a bíróságnak először a felperesnek az egyenlő bánásmód sérelmére történő hivatkozását, és e körben az általa megjelölt Ebktv. 8. §-ában foglalt tulajdonság meglétének valószínüségét kell értékelnie. Mindezekre figyelemmel tehát téves azon álláspont, hogy az Ebktv. 19. § (1) bekezdésében foglalt bizonyítási teher folytán a sérelmet szenvedett félnek azt is valószínüsítenie kell, hogy az általa valószínüsített tulajdonság miatt érte őt a joghátrány. Így tehát bárki akkor marasztalható el az egyenlő bánásmód követelményének megsértése miatt, ha a kifogásolt hátrányt okozó magatartást az adott személlyel, vagy csoporttal szemben a védett tulajdonsága miatt, arra tekintettel tanúsítja.[58] A 19. § (2) bekezdésében foglalt munkáltatót terhelö ún. kimentéses bizonyítási kötelezettség folytán ugyanis az alperesre hárul annak bizonyítása, hogy a jogosult az által valószínüsített körülmények nem állnak fenn, vagy hogy az egyenlő bánásmód követelményét betartotta, vagy az adott jogviszony tekintetében erre nem volt köteles.[59]

A bizonyítás során tehát a felperesnek kell tehát valószínüsítenie, hogy őt hátrány érte, illetve a hátrány bekövetkeztése veszélyezteti, a védett tulajdonsággal rendelkezik, és a csoporthoz tartozik (vagy a munkáltató azt hitte abba a csoportba tartozik). Az alperesnek pedig azt kell bizonyítania, hogy nem történt hátrányos megkülönböztetés, így a felperes által valószínüsítettek nem állnak fenn, megtartotta egyenlö bánásmód követelményét, avagy volt ugyan megkülönböztetés, de azért, mert nem volt köteles megtartani az egyenlő bánásmód követelményét.

Végezetül szólnék arról, hogyan bizonyítható az egyenlő bánásmód követelményének megsértése egy adott ügyben, milyen bizonyítékokkal támasztható alá a felperesi, esetlegesen az alperesi állítás.[60] Az egyenlő bánásmód követelményének megsértését bizonyíthatja például:

- Tanúvallomások:

o Az „ideális” tanúnak a munkáltató korábbi munkavállalóit tekinthetjük, mivel a jelenleg is munkaviszonyban álló alkalmazottaknál fennáll a veszélye annak, 
hogy ők lesznek a „következő áldozatok”, féltik a munkahelyüket. Ezért ha lehetőség van rá, hasznos lehet az ilyen munkavállalóktól írásbeli tanúvallomást beszerezni.

o A felperes személyes meghallgatása

o Olyan tanúk meghallgatása, akiknek hallomásból lehet az ügy szempontjából lényeges tényről tudomásuk.

- Dokumentumok: levelezés, közlemény, e-mailek, a munkáltatónál rendelkezésre álló adatok (pl.: emlékeztetők, feljegyzések, utasítások, statisztikák)

- Egyéb bizonyítékok: álláshirdetés, az interjún elhangzottak, megjegyzések, munkavégzési feltételek mibenléte, munkavégzésre vonatkozó egészségügyi és biztonsági szabályok.

További támpont lehet az, hogyan járt el a munkáltató a sérelmet szenvedett munkáltató által benyújtott panasz esetén: reagált-e a panaszra, azt kivizsgálta-e, és ha igen, mennyire alaposan, alkalmazott-e a panaszt tevővel szemben retorziót.

\section{Záró gondolatok}

Amint azt bevezetésemben is említettem egyre több esetben fordul elö, és már-már kivételesnek számít az, ha a munkaviszony megszüntetésének megtámadásakor a munkavállalók nem hivatkoznak az egyenlő bánásmód megsértésére. Mindezért egyre hangsúlyosabban kell a munkaügyi bíróságoknak figyelmet fordítaniuk az ilyen ügyekben felmerülő problémák hatékony, illetve hatékonyabb megoldására. A sajátosan alakuló bizonyítási tehernek köszönhetően, a sérelmet szenvedett munkavállalónak csupán valószínüsítenie kell az egyenlő bánásmód követelményének megsértését, ezért mindenképpen helytelen gyakorlat, ha a bíróság ilyen esetekben is teljes bizonyossággal kíván meggyőződni arról, hogy tényleg történt-e hátrányos megkülönböztetés.

A jogalkalmazás során további problémaként jelentkezhet magának a hátrányos megkülönböztetésnek a megállapítása is, ugyanis számos esetben a munkavállalók keresetlevébe, a „végső" hivatkozási alapként kerül elö, és maguk a felperesek sem megfelelően hivatkoznak rá, azonban a bíróságnak ekkor is fennáll a kötelezettsége, hogy érdemben vizsgálja öket. Jó néhány esetben elöfordul az is, hogy a felperesek abban a hiszemben vannak, elegendö megemlíteniük, illetve hivatkozniuk az egyenlő bánásmód megsértésére (pl.: azért bocsátottak el, mert teherbe estem), és onnantól kezdve úgymond semmi különösebb dolguk nincs. Ezen esetekben a bíróságnak külön figyelmeztetnie kell a felperest a bizonyítási teherről, és arról, hogy nem elég állítania, hanem valószínüsítenie kell a diszkrimináció megtörténtét. Az ilyen kioktatás során rá kell bírni, hogy kifejezetten jelöljön meg egy védett tulajdonságot, és összehasonlítható csoportot, hiszen megalapozott döntés csak ezt követöen hozható.

Ahogy tanulmányomban is bemutattam, az egyenlő bánásmód követelményének megszegésére történő felperesi kereset elbírálása tehát nem nehéz feladat, nem kíván meg a bírótól többlet energiát, csupán egy kis odafigyelést, és talán egy más oldalú nézőpontot.

Remélem tanulmányommal sikerült a problémásabb kérdésekre választ adnom, megoldást találnom, és így hasznos segédanyagként szolgálhat a jogalkalmazás számára.

Comparison between the requirements of the Court of Justice of the European Union and the Hungarian judicial practice in terms of equal treatment and/or the breach of thereof in the field of labor law - Summary

Employment and occupation are crucial to ensuring equal opportunities for all and in large measure contribute to the full participation of citizens in economic, social and culture life. However, many cases of discrimination have been identified in the field of employment and the labour market. 
In this study I try to examine how the equal treatment works in the EU Law and Hungarian national law, and I try to present the case-law of the European Court of Justice and the Hungarian Courts in this area. The first part of the study deals with the definition of key concepts (direct discrimination, indirect discrimination, harassment), and include its legal background - with respect to the directives of the European Parliament and the Council, and the Hungarian legislation. The second part tries to describe the legal concept of indirect discrimination, mentioned as justification (statutory derogation, objective justification). And finally I try to present the special burden of proof, which is used in discrimination cases.

\section{Irodalomjegyzék:}

Prof. Dr. Klaus Michael Alenfelder: Dealing with a disrimination case, ERA Seminar on EU Anti-Discrimination Law, 2013. március 18-19. Trier

Bankó Zoltán - Berke Gyula - Gyulavári Tamás - Kiss György: Válogatás az Európai Bíróság munkajogi ítéleteiböl - Egyenlő bánásmód elve. KJK Kerszöv 2003.

Prof. Dr. Christiane Brors: The Challenge of an Ageing European Population: Legislation and jurisprudence, ERA Seminar on EU Anti-Discrimination Law, 2013. március 18-19. Trier Gyulavári Tamás (szerk).: Az Európai Unió szociális dimenziója. Budapest, 2000 Gyulavári Tamás: A diszkrimináció tilalma a munkaerőpiacon, Kézirat Debreceni Egyetem Szociológia és Szociálpolitika Tanszék, 2010.

Gyulavári Tamás: Egyenlők és egyenlőbbek (3. rész), Humán Szaldó, 2009/4.

Gyulavári Tamás - Kádár András Kristóf: A magyar antidiszkriminációs jog vázlata, Bíbor Kiadó, Miskolc, 2009.

Hős Nikolett: Az általános jogelvek és az Alapjogi Charta szerepe az Európai Bíróság életkoron alapuló hátrányos megkülönböztetéssel kapcsolatos joggyakorlatában, Magyar Munkajog, E-folyóirat, 2014/1.

Kiss György (szerk.): Az európai unió munkajoga, Osiris Kiadó 2001.

Lehoczkyné Kollonay Csilla: Árnyak és árnyalatok az egyenlő bánásmód európai uniós elvének alkalmazása körül, Fundamentum, 1998/1-2.

Mary Stacey: The Burden of Proof In Discrimination cases, ERA Seminar on EU AntiDiscrimination Law, 2013. március 18-19. Trier

Prof. Dr. Christina Tobler: Direct/indirect disrimination and harresment: key concepts in EU Anti-Discrimination Law, ERA Seminar on EU Anti-Discrimination Law, 2013. március 1819. Trier

Várnay Ernő-Papp Mónika: Az Európai Unió joga, CompLex Kiadó, 2010., Budapest http://szse.eu/wpcontent/uploads/2012/07/20_Egyen1\%C5\%91B\%C3\%A1n\%C3\%A1sm\%C3\%B3d_Uni\%C3 $\%$ B3sPolg.pps.

http://europa.eu/legislation_summaries/human_rights/fundamental_rights_within_european_u nion/em0008_hu.htm

\section{Felhasznált jogesetek:}

EBH 2010. 2272.

EBH 2010.2155.

EBH 2009.1980.

BH 2013. 348.

BH 2008. 250.

BH 2007. 1629

BH 2003. 86.

MK 97. 
C-415/10. számú Galina Meister kontra Speech Design Carrier Systems GmbH ügy

C-104/10. számú Patrick Kelly kontra National University of Ireland (University College,

Dublin) ügy

C-447/09. számú Reinhard Prigge és társai kontra Deutsche Lufthansa AG ügy

C-45/09. számú Gisela Rosenbladt kontra Oellerking Gebäudereinigungsges. mbH ügy

C-229/08. számú Colin Wolf kontra Stadt Frankfurt am Main ügy

C-54/07. sz. Centrum voor gelijkheid van kansen en voor racismebestrijding kontra Firma

Feryn NV ügy

C-555/07. számú Seda Kücükdeveci kontra Swedex GmbH \& Co. KG ügy

C- 267/06. számú Tadao Maruko kontra Versorgungsanstalt der deutschen Bühnen ügy

C-303/06. S. Coleman kontra Attride Law és Steve Law ügy

C13/05. sz. Sonia Chacón Navas kontra Eurest Colectividades SA ügy

C-411/05. számú Félix Palacios de la Villa kontra Cortefiel Servicios SA ügy

C-144/04. számú Werner Mangold kontra Rüdiger Helm ügy

[1]Gyulavári Tamás: A diszkrimináció tilalma a munkaerőpiacon, Kézirat Debreceni Egyetem Szociológia és Szociálpolitika Tanszék, 2010, 2.

[2] Gyulavári Tamás (szerk.).: Az Európai Unió szociális dimenziója. Budapest, 2000.

[3] A Charta ugyan az alapszerződésekkel azonos rangon áll, azonban jogi súlya még mindig nem tisztázott, az Európai Bíróság joggyakorlata is folyamatosan alakulóban van e tekintetben, viszont az elmondható, hogy a Charta rendelkezéseire általánosságban nem lehet hivatkozni, konkrét Uniós joghelyzet szükséges.

[4] Ez a megállapítás általában is igaz az Európai Bíróság ítélkezési gyakorlatára (ennek áttekintésére lásd különösen Sara Iglesias Sánchez (2012): The Court and the Charter: the impact of the entry into force of the Lisbon Treaty on the ECJ's approach to fundamental rights. Common Market Law Review,2012. 49. szám, 1565-1612 o.) Munkajogi és szociálpolitikai gyakorlattal kapcsolatban lásd Berke Gyula (2013): Az Európai Unió Alapjogi Chartájának alkalmazása munkajogi (szociálpolitikai) ügyekben. Lex HR Munkajog, 2013. 11. sz., in: Hős Nikolett: Az általános jogelvek és az Alapjogi Charta szerepe az Európai Bíróság életkoron alapuló hátrányos megkülönböztetéssel kapcsolatos joggyakorlatában, Magyar Munkajog, E-folyóirat, 2014/1. 1164.

[5] Hős Nikolett: Az általános jogelvek és az Alapjogi Charta szerepe az Európai Bíróság életkoron alapuló hátrányos megkülönböztetéssel kapcsolatos joggyakorlatában, Magyar Munkajog, E-folyóirat, 2014/1. 65-66.

[6] Az Európai Bíróság elutasítja az irányelvek horizontális hatályát, azonban a C-555/07. számú Seda Kücükdeveci kontra Swedex GmbH \& Co. KG ügyben az eddigieknél közelebb került az irányelvi rendelkezések ilyen jellegü hatályának az elismeréséhez. A Bíróság rögzítette, hogy maga az említett irányelv nem mondja ki a foglalkozás és munkavégzés során alkalmazott egyenlő bánásmód elvét, az elv különböző nemzetközi megállapodásokból, a tagállamok közös alkotmányos hagyományaiból ered, továbbá az Unió immár kötelező erejü Alapjogi Chartájának 21. cikk (1) bekezdése is magába foglalja az életkor szerinti megkülönböztetés általános tilalmát. in: Várnay Ernő-Papp Mónika: Az Európai Unió joga, CompLex Kiadó, 2010., Budapest, 327.

[7] Lehoczkyné Kollonay Csilla: Árnyak és árnyalatok az egyenlő bánásmód európai uniós elvének alkalmazása körül, Fundamentum, 1998/1-2. 88-93.

[8] Gyulavári Tamás: A diszkrimináció tilalma a munkaerőpiacon Kézirat Debreceni Egyetem Szociológia és Szociálpolitika Tanszék, 2010, 4. 
[9] Gyulavári Tamás: A diszkrimináció tilalma a munkaerőpiacon Kézirat Debreceni Egyetem Szociológia és Szociálpolitika Tanszék, 2010, 5.

[10] Ebktv. 1.§-a. Ez a fogalom lényegében átveszi a 9/1990. (IV. 25.) AB határozat indokolásának szövegét.

[11] http://szse.eu/wp-

content/uploads/2012/07/20_Egyen1\%C5\%91B\%C3\%A1n\%C3\%A1sm\%C3\%B3d_Uni\%C3

$\%$ B3sPolg.pps.

[12] http://europa.eu/legislation_summaries/human_rights/fundamental_rights_within_europe an_union/em0008_hu.htm

[13] Gyulavári Tamás - Kádár András Kristóf: A magyar antidiszkriminációs jog vázlata, Bíbor Kiadó, Miskolc, 2009. 12.

[14]Prof. Dr. Christina Tobler: Direct/indirect disrimination and harresment: key concepts in EU Anti-Discrimination Law, ERA Seminar on EU Anti-Discrimination Law, 2013. március 18-19. Trier.

[15] Prof. Dr. Christina Tobler: Direct/indirect disrimination and harresment: key concepts in EU Anti-Discrimination Law, ERA Seminar on EU Anti-Discrimination Law, 2013. március 18-19. Trier.

[16] A 2000/78/EK irányelv meghatározásában.

[17] A 2000/43/EK irányelv meghatározásában.

[18] A 2000/78/EK és 2000/43/EK irányelv meghatározásában.

[19] A 2000/78/EK és 2000/43/EK irányelv meghatározásában.

[20] Prof. Dr. Klaus Michael Alenfelder: Dealing with a disrimination case, ERA Seminar on EU Anti-Discrimination Law, 2013. március 18-19. Trier.

[21] Prof. Dr. Christina Tobler: Direct/indirect disrimination and harresment: key concepts in EU Anti-Discrimination Law, ERA Seminar on EU Anti-Discrimination Law, 2013. március 18-19. Trier.

[22] C-303/06. S. Coleman kontra Attride Law és Steve Law ügy 26. pont.

[23] C-303/06. S. Coleman kontra Attride Law és Steve Law ügy 59-61. pont.

[24] Prof. Dr. Christina Tobler: Direct/indirect disrimination and harresment: key concepts in

EU Anti-Discrimination Law, ERA Seminar on EU Anti-Discrimination Law, 2013. március 18-19. Trier.

[25] Gyulavári Tamás: A diszkrimináció tilalma a munkaerőpiacon, Kézirat Debreceni Egyetem Szociológia és Szociálpolitika Tanszék, 2010, 8.

[26] Prof. Dr. Christina Tobler: Direct/indirect disrimination and harresment: key concepts in EU Anti-Discrimination Law, ERA Seminar on EU Anti-Discrimination Law, 2013. március 18-19. Trier

[27] Prof. Dr. Klaus Michael Alenfelder: Dealing with a disrimination case, ERA Seminar on EU Anti-Discrimination Law, 2013. március 18-19. Trier alapján.

[28] C13/05. sz. Sonia Chacón Navas kontra Eurest Colectividades SA ügy 47. pontja

[29] C13/05. sz. Sonia Chacón Navas kontra Eurest Colectividades SA ügy 43. pontja.

[30] C-303/06. S. Coleman kontra Attride Law és Steve Law ügy 38. pontja.

[31] Az Ebktv. A védett tulajdonságok körében nevesíti az egyéb helyzetet, mely lényegében azt a célt szolgálja, hogy a 8. § taxatív felsorolásán kívül eső további tulajdonság is minősülhessen védett tulajdonságnak, vagyis ne mentesülhessen a diszkriminációt előidéző fél kizárólag azon az alapon, hogy a másik fél védett tulajdonsága nem kategorizálható az Ebktv. felsorolása alapján. Ugyanakkor a joggyakorlatban két eltérő álláspont áll egymással szemben, ugyanis egyik oldalról nem zárható ki a széleskörü, kiterjesztő értelmezés sem, hiszen ebben az esetben e rendelkezés elérheti valódi célját, és valóban kellően széles biztosíthatna védelmet a hátrányos megkülönböztetés bármely formájával szemben. Másik oldalról azonban a túlzottan kiterjesztő értelmezés ahhoz vezetne, hogy a bizonyítás szabályai 
részben kiüresednek, részben pedig az Ebktv. védett tulajdonságokról szóló felsorolása is értelmét vesztené, hiszen nem is lenne szükség védett tulajdonságot valószínüsíteni, hanem lényegében elegendő lenne ezt egy bármilyen tulajdonságra korlátozni. Gyulavári Tamás: Egyenlők és egyenlőbbek (3. rész), Humán Szaldó, 2009/4. 100-103., Gyulavári Tamás Kádár András Kristóf: A magyar antidiszkriminációs jog vázlata, Bíbor Kiadó, Miskolc, 2009, 57-58.

[32] Egyenlő Bánásmód Hatóság 22/2006. határozata.

[33]BH 2013.348.

[34] C-54/07. sz. Centrum voor gelijkheid van kansen en voor racismebestrijding kontra Firma Feryn NV ügy 24-25.pontja.

[35] EBH 2009.1980. Adott esetben a Legfelsőbb Bíróság nem találta összehasonlítható helyzetben lévőnek a munkáltató székhelyén dolgozókat a pályamunkásokkal.

[36] EBH 2010.2155. Ebben az esetben a Legfelsőbb Bíróság azért találta egyenlő helyzetben lévő személyeknek a munkáltatónál foglalkoztatott személyeket, mert az alperes olyan országos müködésủ gazdasági társaság, amelynek nagyszámú munkavégzési helyén számos azonos munkakörü munkavállaló dolgozik, akikre az alperes egységes szabályozást alkalmaz mind a munkaköri feltételek, mind a munkaköri bérbesorolás tekintetében. Ezért a perbeli jogkérdés nem volt eldönthető csupán az egyik munkavégzési hely három oktatótiszt munkavállalója bérének összehasonlításával, hanem vizsgálandó volt (az azonos körülmények és szabályozás miatt) az összes többi oktatótiszt munkakörü munkavállaló személyi alapbére.

[37] Prof. Dr. Klaus Michael Alenfelder: Dealing with a disrimination case, ERA Seminar on EU Anti-Discrimination Law, 2013. március 18-19. Trier alapján.

[38] Prof. Dr. Christina Tobler: Direct/indirect disrimination and harresment: key concepts in EU Anti-Discrimination Law, ERA Seminar on EU Anti-Discrimination Law, 2013. március 18-19. Trier.

[39] Az Európai Bíróság C-447/09. számú Reinhard Prigge és társai kontra Deutsche Lufthansa AG ügye alapján.

[40] Prof. Dr. Christiane Brors: The Challenge of an Ageing European Population: Legislation and jurisprudence, ERA Seminar on EU Anti-Discrimination Law, 2013. március 18-19. Trier.

[41] C-447/09. számú Reinhard Prigge és társai kontra Deutsche Lufthansa AG ügy.

[42] C-229/08. számú Colin Wolf kontra Stadt Frankfurt am Main ügy.

[43] C-411/05. számú Félix Palacios de la Villa kontra Cortefiel Servicios SA ügy és C144/04. számú Werner Mangold kontra Rüdiger Helm ügy.

[44] C-555/07. számú Seda Kücükdeveci kontra Swedex GmbH \& Co. KG ügy.

[45] C-45/09. számú Gisela Rosenbladt kontra Oellerking Gebäudereinigungsges. mbH ügy.

[46] C-447/09. számú Reinhard Prigge és társai kontra Deutsche Lufthansa AG ügy.

[47] C-555/07. számú Seda Kücükdeveci kontra Swedex GmbH \& Co. KG ügy 42-43. pontja. (A fenti megfontolások összességéböl következik, hogy az első kérdésre azt a választ kell adni, hogy a közösségi jog, különösen pedig a 2000/78 irányelv által pontosított, életkoron alapuló hátrányos megkülönböztetés tilalmát úgy kell értelmezni, hogy azzal ellentétes az olyan nemzeti szabályozás, mint amilyen az alapügybeli, amely elöírja, hogy a felmondási idő számításánál a munkavállaló által a 25. életévének betöltése előtt munkaviszonyban töltött idő nem vehető figyelembe.)

[48] C--45/09. számú Gisela Rosenbladt kontra Oellerking Gebäudereinigungsges. mbH ügy 75-76. pontja.

[49] Hős Nikolett: Az általános jogelvek és az Alapjogi Charta szerepe az Európai Bíróság életkoron alapuló hátrányos megkülönböztetéssel kapcsolatos joggyakorlatában, Magyar Munkajog, E-folyóirat, 2014/1. 60.

[50] MK 97. 
[51] BH 2008. 250.

[52] BH 2003. 86.

[53] Prof. Dr. Christina Tobler: Direct/indirect disrimination and harresment: key concepts in EU Anti-Discrimination Law, ERA Seminar on EU Anti-Discrimination Law, 2013. március 18-19. Trier.

[54] C- 267/06. számú Tadao Maruko kontra Versorgungsanstalt der deutschen Bühnen ügy.

[55] Mary Stacey: The Burden of Proof In Discrimination cases, ERA Seminar on EU AntiDiscrimination Law, 2013. március 18-19. Trier.

[56] C-104/10. számú Patrick Kelly kontra National University of Ireland (University College, Dublin) ügy 39., 43-44., 48. és 56. pontja.

[57] C-415/10. számú Galina Meister kontra Speech Design Carrier Systems GmbH ügy. [58] EBH 2010. 2272.

[59] BH 2013. 348 és BH 2007. 1629.

[60] Prof. Dr. Klaus Michael Alenfelder: Dealing with a disrimination case, ERA Seminar on EU Anti-Discrimination Law, 2013. március 18-19. Trier alapján. 